\title{
Preference for Imported and Nigeria Rice among Rural Households in Imo State Nigeria \\ https://dx.doi.org/10.4314/jae.v22i3.6
}

\section{Onu, Samson Ejike}

Department of Rural Sociology and Extension

Michael Okpara University of Agriculture, Umudike

onu.ejike@moua.edu.ng \& samsononu@gmail.com

\section{Abstract}

This study examined the preference for imported and Nigeria rice among rural households in Imo State, Nigeria. The specific objectives were to ascertain the level of preference of imported and Nigerian rice, determine the factors influencing household preference of imported and Nigerian rice consumed and to identify the major constraints to the consumption of imported and Nigerian rice in the study area. Multi-stage random sampling technique was used in selecting120 respondents. Primary data were collected with the used of structured questionnaire. Data collected were analysed with both descriptive and inferential statistics. The major findings showed that the grand mean score of 2.67 and 1.60 revealed that the respondents preferred imported rice to Nigerian rice. The major constraints to rice consumption preference for Nigerian rice were presence of husk, dirt and stones (90.0\%), poor quality (85.8\%), broken grain (75.0\%), low swelling capacity (72.50\%) breakages (71.60\%), lack of competition advantages (68.33\%), the constraints to imported rice consumption were high cost (73.33\%) and affordability of the products (62.50\%). Factors that significantly influence the household consumption preference for imported and Nigerian rice were price $(p<0.05)$, nutritional value $(p<0.05)$, ease of preparation $(p<0.01)$ cleanliness $(p<0.01)$ and taste $(p<0.05)$. The study concluded that rural dwellers still preferred imported rice to Nigerian rice. It was recommended that Nigerian rice producer should improve the quality of the rice for it to have competitive advantage over imported rice. Government should invest in Nigerian rice production by issuing loans to Nigerian rice farmers and encourage mechanization.

Keywords: imported and Nigerian rice, consumption, preference, rural households.

\section{Introduction}

Rice is the seed of the grass species Oryza sativa (Asian rice) or Oryza glaberrima (African rice). Rice is the most commonly cultivated cereal throughout the world today (Oko and Ugwu, 2010). The African rice is believed to have originated from the wild rice (O. barthii) about 3500 years ago and was domesticated in the inland delta area of Nigeria from where it spread to other parts of Africa.

Rice accounts for over $20 \%$ of global calorie intake and has been an important food commodity for most people in Sub-Saharan Africa particularly in the West African region. In Nigeria, rice has assumed a strategic position in the food basket of rural and urban households. (Oyinbo et al., 2015). It has changed from being a luxury to a necessity which consumption will continue to increase with per capita GDP growth, thus implying that its importance in the Nigerian diet as a major food item for food security will increase as economic growth continues (Ojogho and Alufohai, 2010). 
Creative commons User License: CC BY-NC-ND

Abstracted by: EBSCOhost, Electronic Journals Service (EJS), Google Scholar, Journal Seek, Scientific Commons,

Food and Agricultural Organization (FAO), CABI and Scopus
Journal of Agricultural Extension

Vol. 22 (3) October, 2018

ISSN(e): 24086851; ISSN(Print); 1119944X

http://journal.aesonnigeria.org

http://www.aiol.info/index.php/iae

Email: editorinchief@aesonnigeria.org

The status of rice as being a necessity in the households' food basket is a pointer to the growing consumer preference for rice in Nigeria (Oyinbo et al., 2015). Nigeria currently doubles as the largest rice producing nation in West African sub-region and the second largest importer of rice in the world. This anomaly is attributed to the inability of its Nigerian production to meet up with its demand which has been soaring at a very fast rate over the years. Nigeria's fertile land and rich agro-climatic conditions could easily produce rice to feed the entire country and generate surplus. However, Nigeria has continued to depend on importation from countries like China and Thailand to meet the increasing demand for rice by households.

A combination of various factors seems to have triggered the structural increase in rice consumption over the years with consumption broadening across all socioeconomic classes, including the poor. Rising demand is as a result of increasing population growth and income level (BERNAS, 2015). Rice has become a staple food in Nigeria such that every household; both the rich and the poor consumes a great quantity (Godwin, 2012). In a bid to achieve rice self-sufficiency in Nigeria, a rice transformation action plan was set up in 2011 under the umbrella of the Agricultural Transformation Agenda (ATA) and the target was 6.0 million metric tonnes per annum of Nigerian produced and internationally competitive milled rice by 2015 (FMARD, 2012).

Milled rice consumption has increased significantly over the years from 240 metric tonnes in 1961 to 850 metric tonnes in 1981, and 2757 metric tonnes in 1991 to 4970 metric tonnes in 2011 (FAO, 2014). Nigerian production has not been able to keep pace with the increase in rice consumption over the years which has resulted into a demand-supply gap for milled rice in Nigeria (BERNAS, 2015). The incidence of demand-supply gap for rice in Nigeria has been an existing trend over the years and the trend would continue if appropriate measures are not taken despite the country's huge potential for rice production (Oyinbo et al., 2015). Over the years, Nigeria has relied upon the importation of rice to meet its growing demand for rice but the increased demand in recent years reflect more of increases in the demand for imported rice brands to meet the shortfalls in domestic demand and to meet consumers demand in the urban areas. The importation of rice to bridge the demandsupply gap is worth N365 billion (Ayanwale and Amusan, 2012). The cost of these rice imports represents a significant amount of lost earnings for the country in terms of jobs and income (Bamba et al., 2010).

Akaeze (2010) argued that, the quality of imported rice is far better than the Nigerian produced rice. Emodi and Madukwe (2011) reported that households are dissatisfied with Nigerian rice bought in the market and are weary of picking stones from the Nigerian rice and having to wash it several times. Achieving self sufficiency in rice production and consumption is not a function of only planting large hectares of land with rice neither does it end at producing millions of tonnes of paddy rice. The quality and quantity of processed Nigerian rice available in the market and having the quality desired by consumers closes the rice import gap. 
Creative commons User License: CC BY-NC-ND

Abstracted by: EBSCOhost, Electronic Journals Service (EJS),

Google Scholar, Journal Seek, Scientific Commons,

Food and Agricultural Organization (FAO), CABI and Scopus
Journal of Agricultural Extension

Vol. 22 (3) October, 2018

ISSN(e): 24086851; ISSN(Print); 1119944X

http://journal.aesonnigeria.org

http://www.aiol.info/index.php/iae

Email: editorinchief@aesonnigeria.org

\section{Statement of the Problem}

The majority of rice production and processing in Nigeria is in the hands of resource poor subsistent farmers who lack the economic and social power to fully adopt technologies. Availability of a sustainable rice processing technology for Nigerian resource-poor rice farmers is important if the country's effort at achieving selfsufficiency in rice production must be achieved. However, generating agricultural technologies is meaningful only when they are adopted at the farm level.

However, considerable previous research studies have focused on identifying the constraints to increasing domestic rice production in Nigeria (Olorunfemi, 2014; and Ekeleme et al. 2009). Other studies have focused on explaining the growth of rice consumption. There exists little empirical information on the determinants of rice consumption preference between imported and Nigerian rice at the household level. This constitutes the gap in research that this study is designed to fill. Therefore, this study is carried out to examine consumption preference between imported and Nigerian rice among rural housholds in Imo State.

\section{Objectives of the Study}

The broad objective of this study was to determine the consumption preference between imported and Nigerian rice among rural household among rural households in Imo State. The specific objectives were to:

1. ascertain the level of preference of Nigerian and imported rice;

2. determine the factors influencing household preference of imported and Nigerian rice ; and

3. identify the major constraints to the consumption of imported and Nigerian rice.

\section{Hypothesis}

$\mathrm{HO}$ 1: There is no significant difference between the level of preference for Nigerian rice and imported rice.

\section{Methodology}

The study was conducted in Imo State, Nigeria. T Imo State lies between latitudes $5 \circ$ 12 and $5 \circ 56$ North of the equator and longitude $6^{\circ} 38$ and $7^{0} 25$ East of the Greenwich meridian (Imo State Annual Gazette, 2002). Imo state falls within the rainforest zone of Nigeria with the various characteristics of tropical rainforest zone. The state has an average population density of about 590 persons per square kilometer and its total population of 2006 National Census was 3,927,563. The State is bounded in the East by Abia state, in the west by Anambra and Delta states, in the north by Enugu State and in the south by Rivers State.

The study made use of multi-stage random sampling techniques. From the 27 Local Government Areas in Imo State, 6 (six) Local Government Areas were selected randomly, two each from the three agricultural zones (Owerri, Okigwe and Orlu zones). Twenty (20) respondents were randomly selected from each of the six Local Government Areas. This made a total of hundred and twenty (120) rural households which constitutes the sample size of the study. Primary data were collected for this study. The primary data were collected using a structured questionnaires from household. Data were collected on all the specific objectives of the study. Data 
collected were analysed with both descriptive and inferential statistics. Frequency, percentages, mean count and standard deviation were used in presenting data while tobit regression and $z$ - test were used in testing the hypothesis.

\section{Model Specification}

Objective 2 was analysed using Tobit regression analysis as specified;

Since the levels of preference of rice (imported and Nigerian) cannot be negative (the threshold is zero). The dependent variable can be written using an index function approach.

$$
\begin{aligned}
& l_{i}=B^{\top} X+e_{i} . \\
& Y_{i}=O \text { if } I_{i}=T \\
& Y_{i}=I \text { if } I>T . . \\
& \text { Where: }
\end{aligned}
$$

Y represents a limited dependent variable, which simultaneously measures the preference of rice

$\mathrm{I}^{\mathrm{X}}$ is an underlying latent variable that indexes level of preference

$T$ is an observed threshold level

$X$ is the vector of independent variables influencing preference of Nigerian or imported rice

$\beta i$ is a vector of parameters to be estimated

ei $=$ error term.

If the non-variable $T$, becomes a continuous function of the independent variables and $\mathrm{O}$ otherwise for the generated case

The value of log likelihood function is given as, empirical model is presented below; $\mathrm{Y}=f\left(\mathrm{X}_{1}, \mathrm{X}_{2}, \mathrm{X}_{3}, \mathrm{X}_{4}, \mathrm{X}_{5}, \mathrm{X}_{6}\right.$, $\left.\mathrm{X}_{13}+\mathrm{ei}\right)$

$\mathrm{Y}=$ level of preference (measured by mean preference scores of the respondents)

$Y_{1}=$ preference of Nigerian rice (mean)

$\mathrm{Y}_{2}=$ consumption preference of imported rice (mean)

$\mathrm{X}_{1}=$ Price (yes $=1$, otherwise $=0$ )

$\mathrm{X}_{2}=$ Nutritive value (yes $=1$, otherwise $=0$ )

$\mathrm{X}_{3}=$ Taste $($ yes $=1$, otherwise $=0$ )

$\mathrm{X}_{4}=$ Ease of preparation (yes $=1$, otherwise $=0$ )

$\mathrm{X}_{5}=$ Grain shape (yes $=1$, otherwise $=0$ )

$\mathrm{X}_{6}=$ Cleanliness (yes $=1$, otherwise $=0$ )

$\mathrm{X}_{7}=$ Swelling capacity (yes $=1$, otherwise $=0$ )

$\mathrm{X}_{8}=$ Flavour (yes $=1$, otherwise $=0$ )

$\mathrm{X}_{9}=$ Whiteness $($ yes $=1$, otherwise $=0$ )

$\mathrm{X}_{10}=$ Stickiness (yes $=1$, otherwise $=0$ )

$\mathrm{X}_{11}=$ Rate of breakage (yes $=1$, otherwise $=0$ )

$\mathrm{e}_{\mathrm{i}}=$ Error term

\section{Result and Discussion}

\section{Consumption Preference of Imported and Nigerian Rice}

Table 1 reveals a grand mean of 1.60 for Nigerian rice and 2.67 for imported rice. This result implies that the respondents prefer imported rice more than Nigerian rice in the study area. This is in line with Bamidele et al (2010) that rural household preferred imported rice due to its high quality and grade. Oyinbo et al (2015) also noted that 
Creative commons User License: CC BY-NC-ND

Abstracted by: EBSCOhost, Electronic Journals Service (EJS),

Google Scholar, Journal Seek, Scientific Commons,

Food and Agricultural Organization (FAO), CABI and Scopus
Journal of Agricultural Extension

Vol. 22 (3) October, 2018

ISSN(e): 24086851; ISSN(Print); 1119944X

http://journal.aesonnigeria.org

http://www.ajol.info/index.php/iae

Email: editorinchief@aesonnigeria.org

cleanliness, swelling capacity, Availability and grain shape contributes to household preference for imported rice. According to Olorunfemi (2014). Nigerians have developed a tremendous taste for good quality rice and they will continue to measure the quality and competitiveness of domestic rice by the current standard and quality found in imported rice.

Table 1: Consumption preference of imported and Nigerian rice in the study area

\begin{tabular}{|c|c|c|c|c|}
\hline \multirow[t]{2}{*}{ Forms of rice consumption } & \multicolumn{2}{|c|}{ Nigerian rice } & \multicolumn{2}{|c|}{ Imported rice } \\
\hline & Mean & SD & Mean & SD \\
\hline White rice & 1.83 & $\begin{array}{l}0.41 \\
7\end{array}$ & 2.57 & 0.874 \\
\hline Jellof rice & 2.15 & $\begin{array}{l}0.61 \\
9\end{array}$ & 2.40 & 0.877 \\
\hline Fried rice & 0.89 & $\begin{array}{l}0.57 \\
2\end{array}$ & 2.81 & 0.772 \\
\hline Other forms & 1.51 & $\begin{array}{l}0.57 \\
0\end{array}$ & 2.49 & 0.680 \\
\hline Grand mean & & & 2.67 & \\
\hline Benchmark mean & & & 2.0 & \\
\hline
\end{tabular}

Source: Field Survey, 2017

Key: Mean > 2.0 implies high preference while mean $<2.0$ implies low preference.

\section{Factors Influencing Preference for Imported and Nigerian Rice}

Table 2 shows that the Tobit regression estimate of factors influencing respondents' preference for imported and Nigerian rice in the study area. The result reveals the pseudo $\mathrm{R}^{2}$ value of 0.0787 for Nigerian and 0.5078 for imported rice, this implies that about $78.7 \%$ (Nigerian rice) and $50.78 \%$ (imported rice) of the variable in the dependent variables were accounted for while other were due to error.

The chi square value for Nigerian rice and imported rice where 323.271 and 425.625 respectively and statistically significant indicating high goodness of fit of the model used for the analysis. The coefficient of price, nutritive value, taste, ease of preparation, cleanliness, swelling capacity, texture, flavour, whiteness, stickiness and rate of breakage were statistically significant and are the influential factors of rice consumption preference in the study area. 
Creative commons User License: CC BY-NC-ND

Abstracted by: EBSCOhost, Electronic Journals Service (EJS), Google Scholar, Journal Seek, Scientific Commons,

Food and Agricultural Organization (FAO), CABI and Scopus
Journal of Agricultural Extension

Vol. 22 (3) October, 2018

ISSN(e): 24086851; ISSN(Print); 1119944X

http://journal.aesonnigeria.org

http://www.ajol.info/index.php/iae

Email: editorinchief@aesonnigeria.org

The coefficient of price is statistically significant at $5 \%$ for both imported and Nigerian rice and positively related at probability level, price influences preference for both imported and Nigerian rice. This implies that price of each commodity influences the ability of the consumers to buy it. This agree with Omonona (2010) who posited that price of rice is negatively related to household expends on rice.

The coefficient of nutritive value is statistically significant at $5 \%$ for Nigerian rice and positively related while it is statistically significant at $10 \%$ for imported rice and positively related. This implies that Nigerian rice is higher in nutritive value than imported rice, this also implies that the higher the quality of Nigerian rice the higher the expends on Nigerian rice, an improve in quality of Nigerian rice will increase patronage as customers believed it has better taste and nutritive value than imported rice, this is supported by Ogundele, (2014) who reported that if the quality of Nigerian rice is improved and made comparable with imported it patronage will increase.

The coefficient of taste in Nigerian rice is statistically significant at $5 \%$ and positively related at probability level. This indicates that Nigerian rice has better taste than imported rice, it agree with Ogundele, (2014) who reported that consumers believe that Nigerian rice has better taste and more nutritious than imported rice.

The coefficient of ease of preparation is found to be negative and significant at $1 \%$ at probability level. This implies that Nigerian rice is not easily prepared due to presence of husks and debris. This finding corroborate the observation of Emodi and Madueke (2011) who reported that consumers are dissatisfied with Nigerian rice bought in the market and are weary of picking stone from Nigerian rice and having to wash it several time.

The coefficient of cleanliness in imported rice is statistically significant at $1 \%$ and positively related at probability level, indicating that imported rice is cleaner than Nigerian Rice. This is in line with the findings of Olorunfemi (2014), who confirms that imported rice cleanliness is the major factor for its patronage in Nigeria at the expense of Nigerian market.

The coefficient of swelling capacity is found to be positive and significant at $1 \%$ at probability level in imported rice, indicating that imported rice has more swelling capacity than Nigerian rice, this is in consonance with Bamidele et al (2010) who noted that household prefer imported rice to Nigerian rice because of higher quality and grade.

The coefficient of texture in imported rice is statistically significant at $1 \%$ and positively related at probability level. This implies that imported rice has better texture than Nigerian rice, this relates to the findings of Abdul et al (2017), who noted that household preference imported to Nigerian rice due to its cleanliness, texture, swelling capacity etc. 
Creative commons User License: CC BY-NC-ND

Abstracted by: EBSCOhost, Electronic Journals Service (EJS),

Google Scholar, Journal Seek, Scientific Commons,

Food and Agricultural Organization (FAO), CABI and Scopus
Journal of Agricultural Extension

Vol. 22 (3) October, 2018

ISSN(e): 24086851; ISSN(Print); 1119944X

http://journal.aesonnigeria.org

http://www.aiol.info/index.php/iae

Email: editorinchief@aesonnigeria.org

Table 2: Factors influencing preference for imported and Nigerian rice

\begin{tabular}{|c|c|c|c|c|c|c|}
\hline Parameter & $\begin{array}{l}\text { Nigerian } \\
\text { Rice } \\
\text { Estimate }\end{array}$ & $\begin{array}{l}\text { Std. } \\
\text { Error }\end{array}$ & Z-value & $\begin{array}{l}\text { Imported } \\
\text { Estimate }\end{array}$ & Std. Error & Z-value \\
\hline Price & 0.012 & 0.007 & $2.795^{\star \star}$ & 0.017 & 0.008 & $1.983^{\star \star}$ \\
\hline Nutritional value & 0.146 & 0.100 & $2.463^{\star *}$ & 0.139 & 0.081 & $1.711^{*}$ \\
\hline Taste & 0.040 & 0.023 & $2.705^{\star *}$ & -0.025 & 0.031 & -0.796 \\
\hline Ease of preparation & 0.000 & 0.000 & $0.5853^{\star \star *}$ & 0.000 & 0.000 & 0.680 \\
\hline Grain shape & 0.023 & 0.058 & $3.389^{\star \star \star}$ & 0.038 & 0.017 & 1.0789 \\
\hline Cleanliness & 0.005 & 0.016 & 0.282 & 0.024 & 0.038 & $5.646^{\star * *}$ \\
\hline Swelling capacity & 0.001 & 0.006 & 0.221 & 0.009 & 0.007 & $3.265^{\star \star \star}$ \\
\hline Texture & 0.000 & 0.000 & 1.505 & 0.000 & 0.000 & $5.027^{\star \star \star}$ \\
\hline Flavour & 0.007 & 0.043 & 0.172 & 0.137 & 0.048 & 0.871 \\
\hline Whiteness & 0.000 & 0.000 & 0.474 & 0.000 & 0.000 & 0.129 \\
\hline Stickiness & 0.000 & 0.000 & 1.474 & 0.000 & 0.000 & 0.425 \\
\hline Rate of breakage & 0.000 & 0.000 & 0.076 & 0.000 & 0.000 & 0.841 \\
\hline Pseudo $\mathrm{R}^{2}$ & 0.0787 & & & 0.5078 & & \\
\hline Log likelihood & -282.1771 & & & 249.891 & & \\
\hline Chi-square & 323.271 & & & 425.657 & & \\
\hline
\end{tabular}

${ }^{*} \mathrm{P} \leq 0.05$

Field Survey, 2017 
Creative commons User License: CC BY-NC-ND

Abstracted by: EBSCOhost, Electronic Journals Service (EJS), Google Scholar, Journal Seek, Scientific Commons,

Food and Agricultural Organization (FAO), CABI and Scopus
Journal of Agricultural Extension

Vol. 22 (3) October, 2018

ISSN(e): 24086851; ISSN(Print); 1119944X

http://journal.aesonnigeria.org

http://www.aiol.info/index.php/iae

Email: editorinchief@aesonnigeria.org

\section{Constraints to Consumption of Imported and Nigerian Rice}

The table 3 shows that for Nigerian rice, presence of husks, dirt and stones (90\%), poor quality $(85.83 \%)$, affordability $(58.33 \%)$, lack of comparative advantage $(68.33 \%)$, broken grains and debris $(72 \%)$, low swelling capacity $(72.50 \%)$, breakages $(71.60 \%)$, where the constraints to the consumption of Nigerian rice in the study area. The result also reveals that high cost $(73.33 \%)$, Affordability $(62.50 \%)$, were the constraints to the consumption of imported rice in the study area. This implies that the consumption of Nigerian rice was faced with several challenges compare to imported rice. This is in consonance with the findings of Abdul et al (2017) that consumers prefer and can afford to pay for high quality imported rice in contrast to domestic rice brands which are considered to be of poor quality because they often contain dirt, stones, chaff and large quantity of broken or irregular grains and so lack competitive advantage against the imported rice brand. This finding also corroborate the observation of Emodi and Madukwe (2011) who reported that consumers are dissatisfied with Nigerian rice bought in the market and are weary of picking stone from Nigerian rice and having to wash it several time.

Table 3: Constraints to consumption

\begin{tabular}{ll|l}
\hline Constraints & $\begin{array}{l}\text { Nigerian rice } \\
\text { Percentage }\end{array}$ & $\begin{array}{l}\text { Imported rice } \\
\text { Percentage }\end{array}$ \\
\hline High cost & 31.67 & 73.33 \\
Presence of husk, dirty and stones & 90.00 & 1.67 \\
Poor quality & 85.83 & 5.00 \\
Affordability of the products & 58.33 & 62.50 \\
Lack of competitive advantage & 68.33 & 10.00 \\
Broken grains and debris & 75.00 & 19.17 \\
Low swelling capacity & 72.50 & 23.33 \\
Breakage & 71.60 & 23.33 \\
Taste & 7.5 & - \\
\hline
\end{tabular}

Source: Field Survey, 2017

*Multiple responses recorded 


\section{Difference in Preference for Imported and Nigerian Rice}

The mean preference value of imported rice 2.67 and Nigerian rice 1.65 and the difference 1.25, this shows that there is a statistical difference in consumption preference between imported and Nigerian rice. The result implies that people prefer imported rice to Nigerian rice in the study area, with reasons being that imported rice has better quality than Nigerian rice. The result therefore concluded that there is significant difference in the consumption preference between imported and Nigerian rice, we therefore rejected the null hypothesis at $5 \%$ probability level.

Table 4: Difference in preference of imported and Nigerian rice in the study area

\begin{tabular}{lllll}
\hline Variables & Mean & $\begin{array}{l}\text { Std. } \\
\text { deviation }\end{array}$ & Std. Error mean & $\mathbf{Z}$ \\
\hline Imported rice $^{\mathrm{A}}$ & 2.67190 & 0.84124 & 0.09779 & \\
Nigerian rice $^{\mathrm{B}}$ & 1.64681 & 0.60950 & 0.11898 & \\
& & & & 4.79
\end{tabular}

Source: Data computed from Field Survey, $2017 \quad{ }^{\star} \mathrm{P} \leq 0.05$

\section{Conclusion and Recommendations}

Imported rice was mostly preferred by the rural dwellers. Preference of either Nigerian or imported rice was influenced by several factors such as high cost, cleanliness, taste, texture, flavour, swelling capacity, and affordability.

Campaigns aim at creating awareness on the negative effect of importing large tons of rice on the development of the nation's rice market should be encouraged. Nigerian rice producer should improve the quality of the rice for it to have competitive advantage over imported rice. Government should invest in Nigerian rice production by issuing loans to Nigerian rice farmers and encourage mechanization. Both government, NGOs and private operators should provide processing facilities to the Nigerian rice producers to enhance the quality. This will enhance the competitive advantage of Nigerian rice with the imported rice.

\section{References}

Abdul Latiff, Z. A. B and Ayob M.A. (2017) Preference of consumer toward imported rice and local rice in Kelantan. Informing Science: International Journal of Community Development \& Management Studies, 1, 73-83, Retrieved from: http://ijcdms.org/Volume01/v1p073-083Latiff4089.pdf

Akaeze, H.O., (2010). Consumer preference for imported rice in Nigeria-perceived quality differences or habit persistence? Thesis Submitted to Michigan State University for the Degree of Master of Science Agricultural, Food and Resource Economics, UMI Dissertation Publishing.

Akande, T. (2001). Overview of the Nigerian Rice Economy. The Nigerian Institute of Social and Economic Research (NISER), Ibadan. 1 Ipp 
Creative commons User License: CC BY-NC-ND

Abstracted by: EBSCOhost, Electronic Journals Service (EJS), Google Scholar, Journal Seek, Scientific Commons,

Food and Agricultural Organization (FAO), CABI and Scopus
Journal of Agricultural Extension

Vol. 22 (3) October, 2018

ISSN(e): 24086851; ISSN(Print); 1119944X

http://journal.aesonnigeria.org

http://www.aiol.info/index.php/iae

Email: editorinchief@aesonnigeria.org

Ayanwale, A.B. and Amusan, C.A. (2012). Gender Analysis of Rice Production Efficiency in Osun State: Implication for the Agricultural Transformation Agenda. Paper presented at the 13th National Conference of the Nigerian Association of Agricultural Economists, Obafemi Owolowo University, Ile -Ife, Nigeria, September 25th - 27th.

Bamba, I., Diagne, A., Manful, J. and Ajayi, A. (2010). Historic Opportunities for Rice Growers in Nigeria. Grain de sel. No. 51, July - September 2010.

Bamidele, F.S, Abayomi, O.O.and Esther, O.A. (2010). Economic Analysis of Rice Consumption Patterns in Nigeria. J. Agr. Sci. Tech. 12(1): 1-11

BERNAS. (2015). Rice Importation and Rice Distribution. Retrieved May 18, 2015, from BERNAS website: http://www.bernas.com.my/index.php/2014-06-27-15-49-00/201406 27-15-49-2.

Ekeleme, F., Kamara A.Y., Oikeh S. O., Omoigui L. O., Amaza P., Abdoulaye T. and Chikoye D. (2009). Response of Upland Rice Cultivars to Weed Competition in the Savannas of West Africa. Crop Protection, 28:90 - 96.

Emodi, A.I. and Madukwe, M.C. (2011). Influence of Consumers' Socio-Economic Characteristics on Rice Consumption in South East Nigeria. Libyan Agriculture Research Center Journal International. 2(3): 105-11 1

Emodi, I.A. and M.U. Dimelu, (2011). Strategies for enhancing rice innovation system in Southeast Nigeria. British Journal of Management and Economics, 2(1): 1-12.

Federal Ministry of Agriculture and Rural Development, (2012). Rice Transformation Team: Achievements up to date.

Food and Agricultural Organization of the United Nations (2012). http://faostat.fao.org/site/

Food and Agriculture Organization (FAO) (2010). FAO Agricultural Bulletin of Statistics 3(2): 15. Rome, Italy. www.fao.org.

Food and Agriculture Organization of the United Nations Statistics Division (FAOSTAT). (2014). Crop production and trade. Rice production, importation harvested area.

Godwin, U. (2012). Rice farm, milling plant: Sure money spinner. Available at: http://nationalmirroronline.net/new/rice-farm-milling-plant-sure-moneyspinner/. Accessed 15th January 2013.

Lançon F., Erenstein O., Akande S. O., Titilola S. O., Akpokodje G. and Ogundele O. O. Lenis, S. O. Gbolagade, B. A. and Oyeleke, R. O. (2009). Enhancing the competiveness of Agricultural commodity chains in Nigeria: Identifying opportunities with cassava,rice, and maize using a policy analysis matrix (YAM) framework. P. 1 10.Background Paper no. NSSP 013.

Ogundele, O. (2014). Factors influencing consumers preference for local rice in Nigeria. African Journal of Marketing Management, 6(4), 49-55

Oko, A.O.; Ubi,B.E. and Efisue, A.A. (2012). A Comparative Study on Nigerian and Newly Introduced Rice Varieties in Ebonyi State of Nigeria based on Selected Agronomic Characteristics. International Journal of Agriculture and Forestry 2(1): 11 - 17. 
Creative commons User License: CC BY-NC-ND

Abstracted by: EBSCOhost, Electronic Journals Service (EJS),

Google Scholar, Journal Seek, Scientific Commons,

Food and Agricultural Organization (FAO), CABI and Scopus
Journal of Agricultural Extension

Vol. 22 (3) October, 2018

ISSN(e): 24086851; ISSN(Print); 1119944X

http://journal.aesonnigeria.org

http://www.ajol.info/index.php/iae

Email: editorinchief@aesonnigeria.org

Olorunfemi O. (2014) Factors influencing consumers preference for local rice in Nigeria. African Journal of Market Management. Vol.6(4) pp, 49-55. ISSN 2141-2421

Omonona, B.T., Nkang, N. M. and Ajao, F. A. (2009). Household Food Demand Analysis: A Survey of Semi-Urban and Rural Households in South-West Nigeria. Global Journal of Pure and Applied Sciences, 15(4): 315 - 324.

Oyinbo O., Omolehin R.A. and Abdulsalam Z. (2015) Household Consumption Preference for Imported and Domestic Rice in Kaduna State, Nigeria: Implication for Rice Quality Improvement. Publication of Nasarawa State University, Keffi. PAT June, 2015; 9 (1):29-37 ISSN: 0794-5213 Online copy available at www.patnsukjournal.net/currentissue 